\title{
Self-management Strategies of Music Teacher in Musical Interpretation Teaching
}

\author{
Ayu Niza Machfauzia \\ Yogyakarta State University, Yogyakarta 55281, Indonesia email : niza.kudrat@gmail.com
}

\begin{abstract}
In this paper, presented the results of a qualitative study of case studies of selfmanagement strategies music teachers in interpretation of music teaching. The purpose of this research is to reveal the self-management strategies that teachers use in interpretation of music teaching. Subjects in this study were teachers who teach musical instrument practice as many as 12 people. In this study subject determined by purposive sampling technique. Interviews, observation, and documentation techniques are used for data collection. The data have been collected from being validated by using triangulation techniques and triangulation time, and analyzed by means of data reduction, data presentation, and inference data. The results showed that components of self-management strategies used by teachers which include motivation, teaching method, and monitoring performance.
\end{abstract}

Keywords: self-management, interpretation of music, music teacher

\section{INTRODUCTION}

In learning music, especially learning how to play instruments, teachers not only transfer all the knowledge related to music, but they also need to embed those knowledge which include teaching a variety of interpretation of music, so that students can understand and apply it when they perform music. It is as described by White (2009:6) that So that the students are able to interpret the music played, the teacher's job to teach students about interpretation of music.Unfortunately, many musicians and teachers music generally focus more on notation and rhythm that is part of the skeleton interpretation. Ford (2011:2) said that developing interpretation of music played, is one of the aspects make music, the most important and enjoyable. This is because, interpretations that can reflects ideas and feelings about music player that played. Thus through interpretation, a player can communicate the emotional connection with the music being played. Conditions such as these occur also in the instrument practice learning at SMK Negeri 2 Poor Bantul, particularly in an interpretation of music learning. In the lesson, the teacher concentrates more on notation and rhythm.

If it is related with a presentation music, it can be said that interpretation of music is important to be taught to the students. Kitelinger (2010:1) explained that a paper music without interpretation is just a music that is written on paper and without 
meaning, without values, and without the clarity of what is written. The same thing was expressed also by Davie (1996:6) that if a music performer just plays what he saw in the sheet music, the results of musical performance will be tedious. Therefore, interpretation of music needs to be taught to students, despite the fact that the interpretation of music teaching is a difficult and complex (Matthay, 1913:1).

\section{MATERIALS AND METHODS}

Based on a preliminary study conducted at SMK N 2 Kasihan Bantul, the data obtained through interviews with 2 teachers practice both instruments, 5 students, as well as the public relations vice principal that 1 ) the majority of the instrument practice teachers lack motivation to develop the ability including to develop capabilities academic; 2) there are many students who do not understand the musical interpretation; 3) the majority of the instrument practice teachers still use teachers-centered learning strategies in any process learning.

Other data obtained through the preliminary observation that in the teaching of interpretation of music, most of the teachers do not explain the objectives to be achieved in the learning. In fact, if teachers can be explain the purpose of the interpretation of music in instruments practice, then learning will be more focused and determined what can be achieved. Some of the problems found in the field are issues that can degrade the quality of learning in schools.

And so, for the purpose of learning musical interpretation can be more focused and obtain maximum results, then teachers need to use a strategy that can help students to think, so that when students play a piece of music, he was really playing music. It is as expressed by Matthay (1913: 2) that the good teaching, not trying to make the students just do something, so that the results of his training efforts look like playing music without interpretation, but teachers can help students to think, so he looks rightactually playing music. Furthermore, Matthay (1913) explains that a good teacher is not trying to turn his students into an automaton, but the teacher tried to encourage students to grow into an intelligent human being.

According to the description, the following questions can be presented; "What strategies can be used by teachers in teaching the interpretation of music?

Effective music teachers are teachers who give their knowledge with passion to be the best (Young, 2010:xvi). Therefore, music teachers need to improve the quality of their experience and the art of teaching music in school itself, so that the purpose and quality of learning can be achieved well. One of the ways to improve the quality of experience and the art of teaching music in school is to itself use self-management strategies. The purpose of the use of self-management strategies is that the teacher is able to deal constructively and effectively with the variables that affect the quality of personal life that includes time management, motivation, goal-setting, stress management, and concentration (Wong, 2009), and this can be applied in interpretation of music teaching. 
From the description above, the purpose of this study is to reveal the self-management strategies that are used by music teachers when teaching musical interpretation.

\section{Self-Management Strategy}

Self-management (Dembo, 2004: 4) in education more leads to a strategy and useful to improve key skills (desirable) that will help an individual throughout his life including one of skill to play music. In other words, self-management is a strategy in which individuals can effectively direct the activities done in the face of achieving goals, including goal setting, decision making, time management, self-evaluation, self-intervention, self-development, self-monitoring, and self-motivated. The same thing is also presented by Zimmerman and Risemberg (1997) in Dembo (2004: 10) states that there are six components in self-management, namely the motivation, methods of learning, use of time, physical environment, social environment, and monitor performance. The use of self-management skills associated with each of these components, can help a person (teacher or student) to take control of their own learning and to improve academic achievement to be achieved.Thus, teachers can use self-management strategies in teaching musical interpretation with reference to the six components that have been submitted. This is especially useful for teachers to improve and develop themselves, especially in the academic field. One of the keys to success in learning (Dembo, 2004: 4) is the practice of learning strategies in the classroom, so that students become automatic learning and motivated to learn.

\section{Types of Research}

This research is a qualitative case study type focused on self-management strategies that can be used by teachers in teaching musical interpretation. The collected data, obtained using the technique of interview, observation, and documentation. The use of case studies in this study (Gerring, 2007:12) for studying the individual (teacher) in depth to help him obtain a good adjustment. In addition, this study is an empirical study that investigates the phenomenon (Yin, 2009:18) in the context of the readiness of teachers in teaching the interpretation of music in the instruments practice classroom. The data was collected validated by triangulation techniques and triangulation time.

\section{Research Subjects and Places}

Subjects in this study were the teachers who teach the practice of instrument in class XII SMK Negeri 2 Kasihan Bantul, amounting to 12 people. Determination of research subjects by using purposive sampling. In addition, involving students who follow the instruments practice learning to support research, amounting to 22 people. Almost all the teachers have experience teaching music in SMK Negeri 2 Poor Bantul approximately 20 years old, and 10 teachers have the undergraduate music education background, while 2 teachers have the diploma music education background. Meanwhile, the students involved in this study already had a musical learning experience for two years (studying music in class X, and XI). SMK Negeri 2 Poor Bantul itself is the only vocational school that organizes learning in the field of music skills, especially western art music of various era. The school is located at Jl. PG. 
Madukismo, Ngestiharjo, Kasihan, Bantul, Yogyakarta. In the implementation of the learning, the use of KTSP (Kurikulum Tingkat Satuan Pendidikan).

\section{Procedures}

Implementation of this research were divided into three phases, namely the pre field, phase field, and post-field phase. In the pre field stage, the first thing to do is take care of the permit addressed to the Principal of SMK Negeri 2 Poor Bantul. This is done to reduce the presence of rejection when researcher entering the field. After that, carry out a preliminary study to find the subject of research, conduct field exploratory (field study), and search for the initial data in order to determine the issues contained in the field to determine the focus of research.

Before doing a preliminary study, researchers conducted a literature review related research topics as scientific confirmation to support research data. Another thing that is done at this stage was to select and utilize the research subjects (the informant), the teachers who teach the practice of instrument as many as 17 people. The determination of this amount is to represent each instrument of music that is taught in the schools where the research took place. In determining the subject of the study, assisted by the head of public relations that provide data about the teachers who teach the instrumental music practice. Having given these data, researcher determined the subject of research by 17 people. Furthermore, the researcher contacted the teachers to seventeen, to convey the intention of the researcher's presence in the school.

The second stage is the stage field. At this stage, researcher began to enter and understanding more about the research place (SMK Negeri 2 Kasihan Bantul) for data collection. Therefore, qualitative research methods put more emphasis on process rather than outcomes, then to meet the accurate results can be seen from the whole process is done, so this research puts the researcher as the primary instrument in extracting and processing the data obtained.

In the course of data collection, researchers active in direct data collection in twelve classes of instruments practice which carried out naturally. This means that, the data collection was doing the time of the teacher was teaching music instruments practices in accordance with the schedule specified by the school. Data retrieval is done by observing the teacher while teaching that focuses on the strategies used by the teacher, and continued with the interview.

Interviews were used in this study was semi standard and conducted face to face, because it gives greater freedom in communicating with research subjects (Satori and Komariah, 2011; Gilham, 2000). Also conducted interviews at the 5 students who actively take part in practice learning the instrument. In this activity, has also been conducted documenting (photographing the activities of teachers in teaching). The change of the number of research subjects from 17 to 12 people due to the difficulty in the process of dividing the time of observation in the classroom, because the schedule practice learning instrument performed at the same hour in each class, ie hours 11:15 a.m to 00:35 p.m. and 00:50 p.m to 2:10 p.m, so the research process can not 
cover the whole subject of research. The twelve teachers are Drs. Gmr I (Clarinet and Saxophone); Brn Ari, S. Sn. (Trumpet); Drs. Stn, M. Pd. (Oboe); Sprj, M. Sn. (Guitar); Fd, M.A. (Violin); Brt brg W, EP. (Cello); Gf Fr. S. Pd. (Violin); Drs. Sdrt (Contra Bas); UTR, S. Sn. (Piano); Drs. Lg SMJ (vocals); and Dra. Yhn L.S. (Vocal). Stage of data collection was conducted in April-August 2012, later extended to December 2012.

The next stage in this research was post-field phase. In this phase, carried out the process of analyzing the data that has been obtained through observation, interviews, and documentation. The data have been analyzed using an interactive model that includes data reduction, data display and conclusion / verification.

\section{DISCUSSION}

Learning strategies (Surya, 2004: 109), is a method to assist students in realizing effective learning behavior in order to achieve the desired goal. In addition, learning strategies covering various aspects of activities that must be performed by teacher in a interactions situation of teaching and learning. Thus, it can be said that it is an action strategy that included the use of methods, approaches, and various learning resources. The strategy used has been developed to achieve the intended purpose. So that strategies can be used effectively, it is necessary to define learning objectives to be achieved. The strategy itself shows activity steps (syntax) (Ihsan, 2008: 7) or procedures used in presenting teaching materials to achieve learning objectives. A strategy chosen to implement learning methods can be chosen so that conditions conducive learning and fun. Therefore, for students to be active in participating in learning a musical interpretation in practice learning the instrument, then in each stage (Ihsan, 2008: 8) teachers need to include: 1) use a variety of learning resources, methods and instructional media; 2 ) provide a learning experience that are meaningful to the students in the act; 3 ) allow for students to grow and develop their ability to think critically, creative, innovative, and productive; and 4) motivate students to explore beyond the materials studied. Learning strategies are used to facilitate music interpretation learning process, especially interpretation of a piece of music being played, so as to achieve optimal results.

Based on these descriptions, the interpretation of the music teaching strategies used by teachers varied in each stage of learning, both in the opening stages (a perception), the implementation phase and the evaluation phase and the final phase (cover). In the opening stages, not all teachers start with a formal atmosphere and prayed. Teachers tend to only give a greeting and immediately asked the previous tasks with a relaxed atmosphere. This is evidenced in the results of observations made in class cello, guitar, trumpet, vocals A, vocals B, piano, contra bass, and oboe. Meanwhile, in class saxophone, clarinet, and violin $\mathrm{A}$, the teacher always started learning to pray and then do the tuning. Here, the teacher shows the students a discipline, ie before playing the instrument needs to be tuned to the instrument prior activities. Teachers can control himself and motivate himself to behave discipline. It is as shown in Figure 1. 


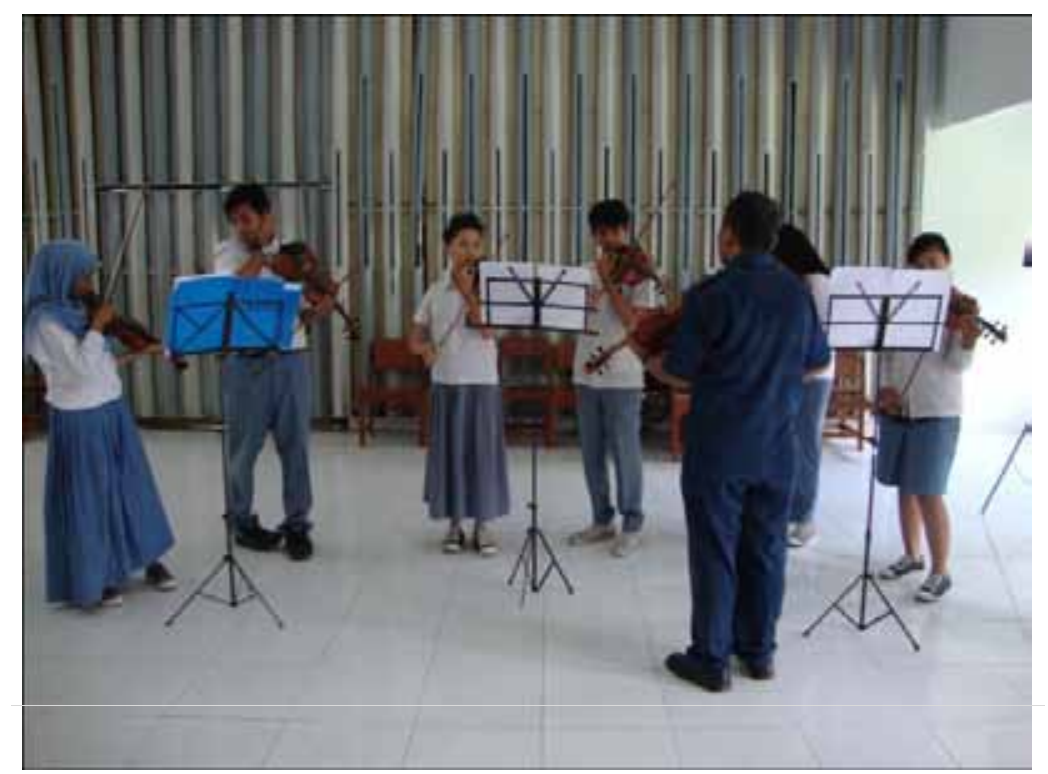

Figure 1. A violin teacher tune together (Collection: Ayu, 2012).

Meanwhile, in the violin class B at the beginning of the lesson, the teacher always asked students to fill out the attendance list first and then ask the tasks given. This strategy can be seen in Figure 2.

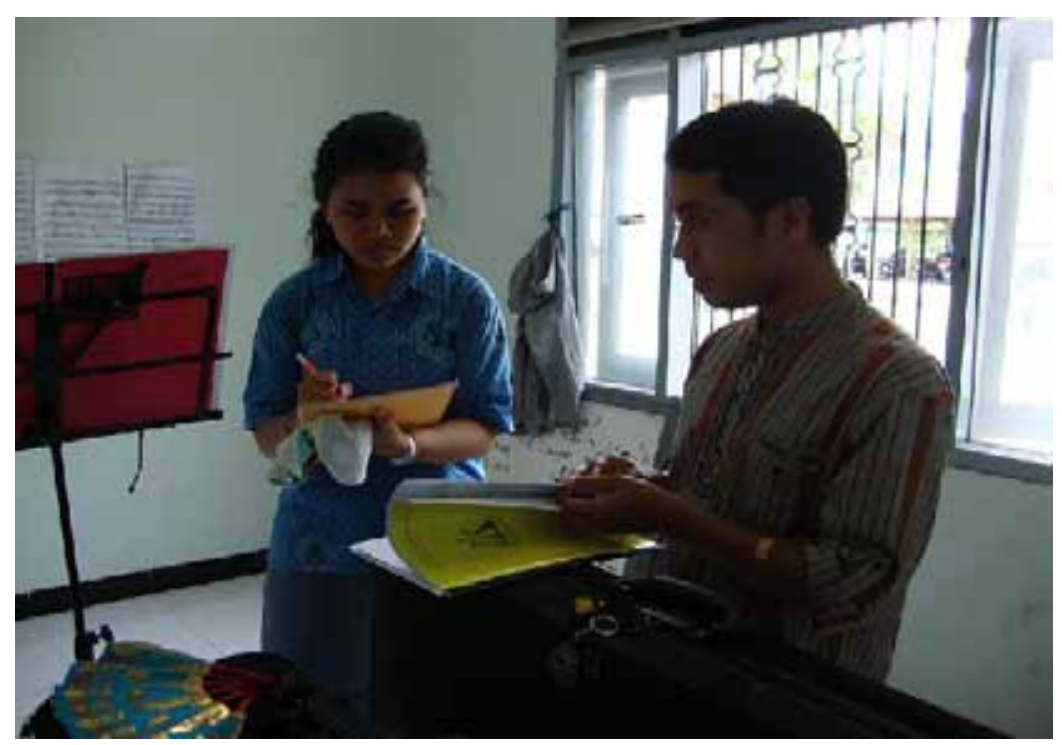

Figure 2. Violin B teacher asked students to fill out the attendance list (Collection: Ayu, 2012).

Figure 1 and Figure 2 show that each of the teachers in learning begin using a variety of strategies that pray, and fill the attendance list. Even some teachers have students do the direct heating, such as in class B vocals, and this activity can be seen in Figure 3. 


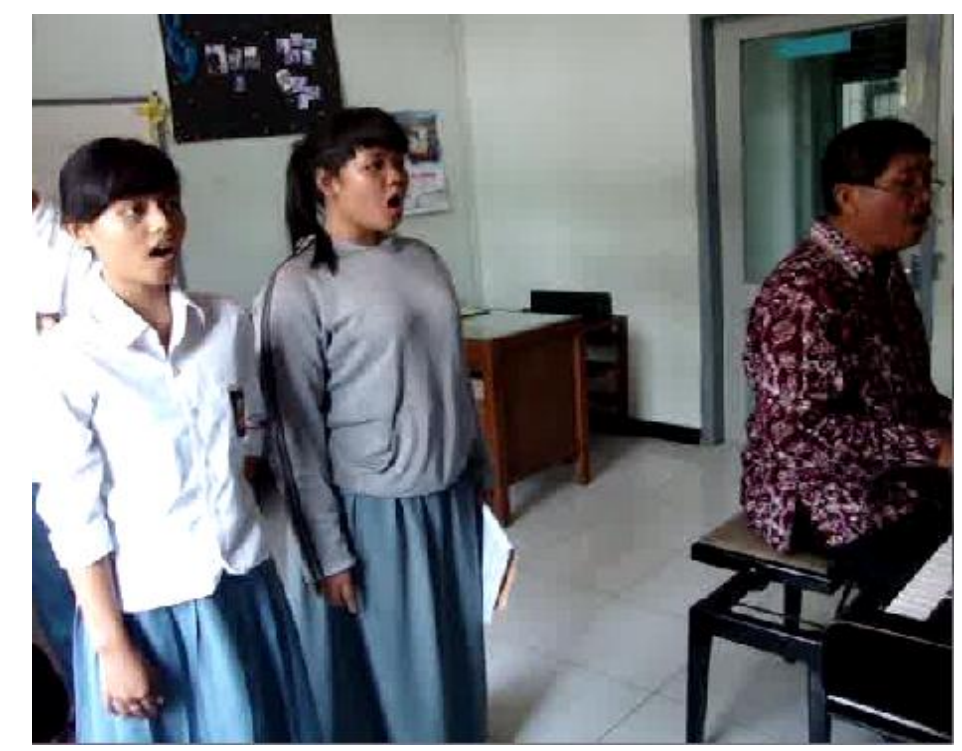

Figure 3. B vocal teacher guiding the students of class XII warming (vokalisi) together (Collection: Ayu, 2012).

Furthermore, at this stage of the implementation of learning musical interpretation, all teachers practice instrument using a variety of methods including methods of imitation, demonstration method, and the method of repetitive exercise (drill). Lecture method is used to describe things that related playing techniques. Imitation method is used to give examples of the students' first game, then students mimic what has been exemplified by the teacher. Demonstration method is used to give an example of playing an instrument that demonstrated by teachers to students, while the method of repetitive exercise (drill) is used to help students provide ease of play in certain parts of the songs that are considered difficult. With the implementation of repetitive training methods are no longer expected that students find difficulty in playing a song is learned. The use of these methods in practice collaborated with each other, and adapted to a variety of factors such as the development of students' skill levels, goals, contents of learning materials, and the environment. If only the methods used by teachers in teaching music interpretation, it may not be able to achieve the learning objectives have been determined. Therefore, the teacher uses a variety of methods in each lesson. The use of such methods can be described through interviews with vocal B teacher ( $\mathrm{Lg} \mathrm{SMJ})$ follows.

"Usually, I give you an example first .. once up to two times. After that, the students tried to sing a song like what I've demonstrated. While the practice, I explain also about vocal techniques, so that they understand". (Mtd)

The activities of teachers in an example for students by using the method of demonstration and imitation method, as shown in Figure 4. 


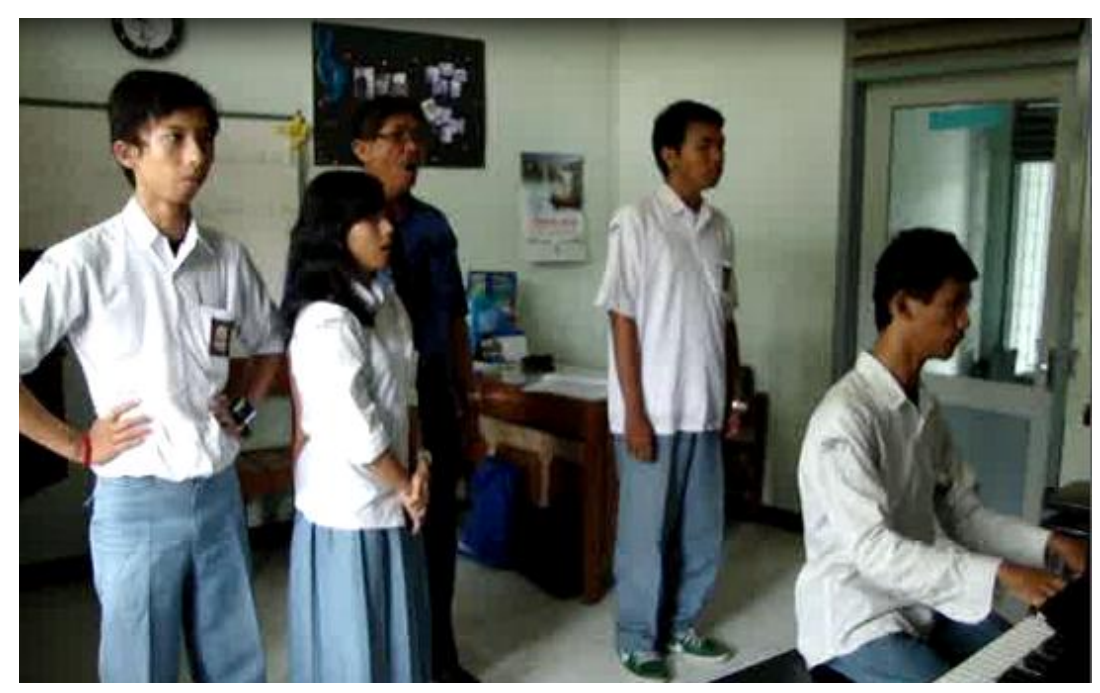

Figure 4. B vocal teacher gives examples of class XII student articulation techniques (Collection: Ayu, 2012).

Based on the pictures and the results of interviews with vocal teacher B ( $\mathrm{Lg} \mathrm{SMJ),}$ can be explained that teachers use demonstration method (shows how to sing with good technique and correct articulation) are combined with the lecture method (explained on articulation techniques). More can be said also that the teacher also uses the method of imitation, because the teacher also gives examples of singing with good technique and correct articulation, then students trying to practice singing by imitating what has been exemplified by the teacher. The use of these methods in the study of music interpretation in vocal class B, was to motivate students to practice the spirit and continue to develop skills and improve their skills in singing. Under these conditions, it can be said that teachers use self-management strategies that include the use of component learning method. Unlike the vocal learning in class B, study of the music interpretation in the saxophone classroom of the class XII, teachers tend to use imitation method and lecture method. This is because the skill level of the students playing instruments is still low. In addition, the motivation of students in the following practice learning the saxophone too low. This is evidenced by the frequency of attendance less in following the learning process. The condition was revealed in the interview with Gmr I (saxophone teacher) as follows.

"Class 3 (XII) is somewhat difficult to develop their skills. Though I have tried motivation but yet succeeded. They are rather lazy to practice the saxophone. So, in teaching this class, I often give the example they mimicked. In addition, I continue to motivate students.". (Mtd).

Based on interviews with the teachers, it can be said that the use of learning strategies in music interpretation, the teacher uses a direct strategy is a strategy with a teachercentered approach (one direction). Meanwhile, the method used is the lecture method, the method of imitation, and the method of demonstration, as well as using the individual approach. These strategies are used according to the conditions of students, 
as well as the condition of the class, and the environment. In addition to using the strategies and methods such as these, some teachers also use audio media. The use of media was done by the teacher in some of classroom of practices, such as vocal class A, vocal class B, cello, and saxophone. In the third class of media used in the form of a set of CD players and laptops, as well as used to accompany students when playing a piece of music is learned. Based on interviews with a vocal teacher A (Yhn LS) revealed that the CD media, CD player, and 14-inch TV that is in a class is a self-financing of the teacher concerned. The media used to accompany students in vocal practice. The reason teachers use the media, because it is difficult to find a pianist who can accompaniment students in vocal practice. Results of interviews with vocal teacher A (Yhn LS) is seen as follows.

"If for piano accompaniment, I bought the tools, let anyone accompany these students sing. Because looking for a piano player that can accompany it hard ". (Strg).

Procurement of audio media is self-financing by the teacher Yhn LS in the classroom vocal A this is an attempt by the teacher to improve students' skills in vocal practice. In fact, this is actually the responsibility of the school to provide a means of both audio and visual media that can be used in the practice of the instrument learning, especially learning the music interpretation. The media in question can be seen in Figure 5.

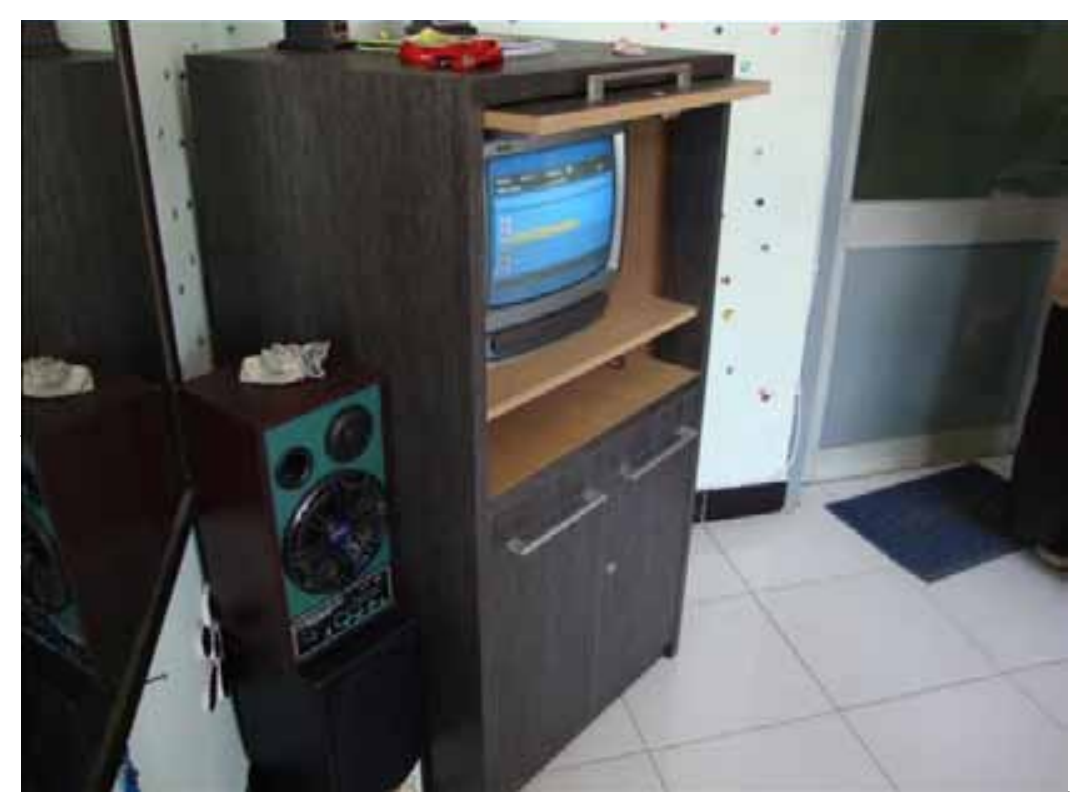

Figure 5. The media used by teachers to accompany students sang (Collection: Ayu, 2012).

With the media as in Figure 5, the teacher can select the desired accompaniment according to the song that will be sung by students. The accompaniment has been packaged in a $C D$, and there are some who become vocal learning materials in the $C D$ accompaniment tracks, as expressed by Yhn LS A vocal teacher follows.

"In the CD there are some accompaniment of songs which being learning materials, so I only choose to live, according to the song that will be sung by the students". (Mda). 
From what has the teacher is doing, it can be said that the teacher uses one component in self-management is motivation. That is, self-motivated teachers to meet the instructional media in its class by bought at his own expense. This is done, so that the student can sing with the accompaniment of music while following the practice of vocal learning. The conditions that occur in a vocal class, also occurred in the saxophone class (class XI), in which the teacher in using the media contained in the media room (provided the school) to accompany the students to play the saxophone. It is as revealed in interviews with Gmr I below.

"Usually, I use this room (media room) for help students play saxophone with accompaniment. I created it's own accompaniment on $C D^{\prime \prime}$. (Md).

Furthermore, the activities of the students of class XI who played saxophone with accompaniment assistance carried in the media room can be seen in Figure 6.

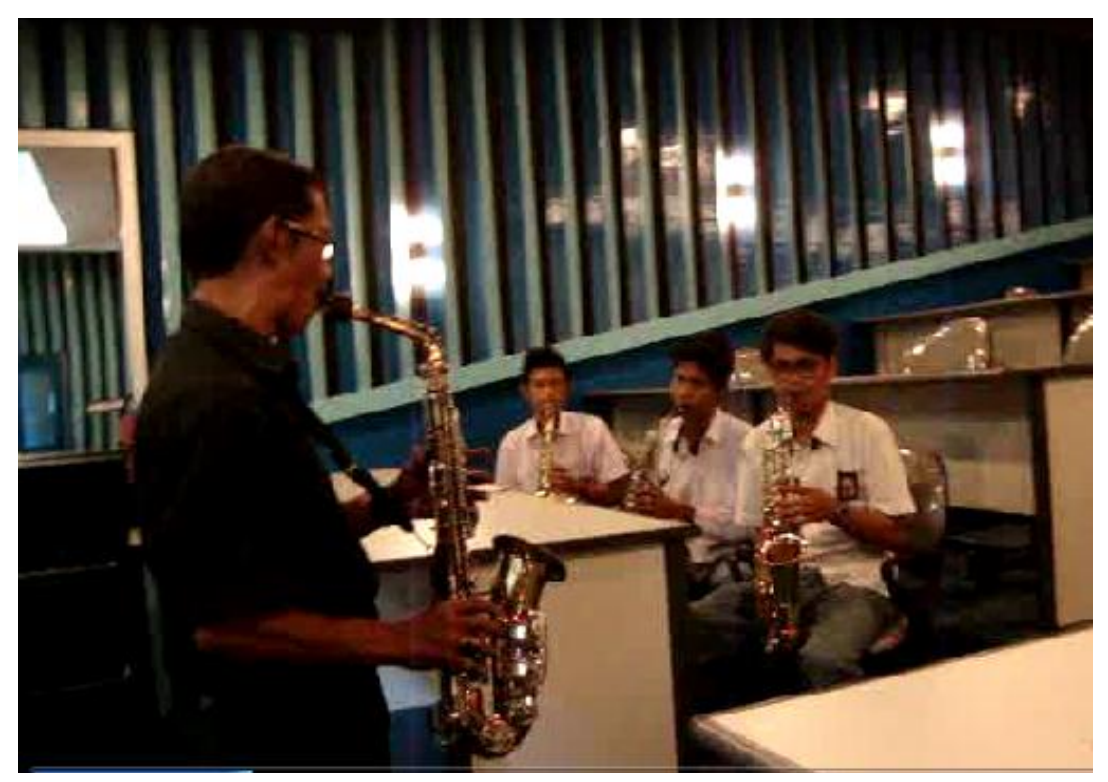

Figure 6. Implementation of saxophone practice learning students class XI using audio media (Collection: Ayu, 2012).

In another class, namely the class cello, the use of media such as laptops made by teachers to accompany students play a piece of music. This activity can be seen in Figure 7. 


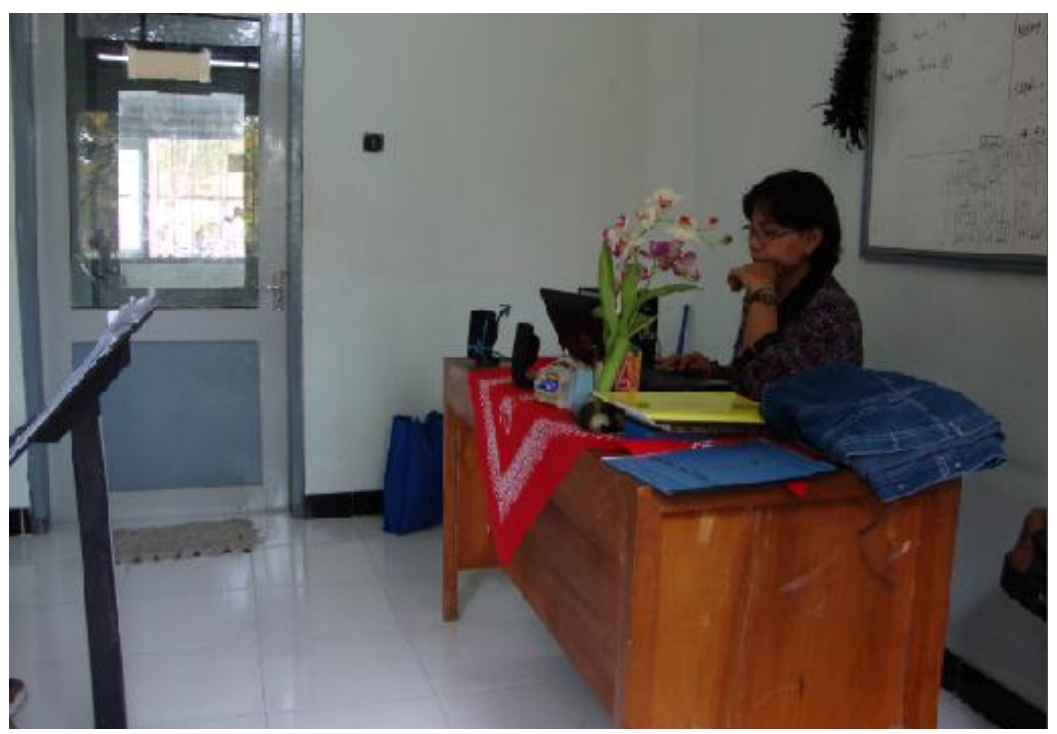

Figure 7. Cello teacher was prepare materials accompaniment music using a laptop (Collection: Ayu, 2012).

The condition is also evidenced by the results of interviews with Brt Brg W, EP (cello teacher) as follows.

"If the students play songs, accompanied with mp3's in a laptop". (Mda).

Of the three conditions, it can be said that a vocal teacher A, saxophone teacher, and cello teacher using only the audio media to accompany the students to play music, not to be heard in detail the elements of the music being played, and then discussed, but only to assist students in playing music. This was done because of the difficulty of finding students who can accompanying a playing instrument these students, so that teachers anticipate using the $C D$ being played using a $C D$ player. In addition to the use of audio media, some teachers in the learning process using an individualized approach. This is done so that learning can be more focused. One of the teachers who use an individualized approach was a cello teacher (Brt Brg W, EP). This is evidenced in the following interviews.

"Here I taught him one by one, ... although the students grade 3 (XII) there are 3, the students grade 2 (XI) there are 4 If I merge all so do not focus ... " (Strg)

Another teacher using the same approach (individual) is a violin teacher B (Fd). The reason for the use of the approach in learning proficiency level is almost the same as what is expressed by a cello teacher. Following expression violin teacher $\mathrm{B}(\mathrm{Fd})$ on the use of an individual approach.

"The learning process is deliberately one-on-one ... let me control it easily, and be more detail". (Strg)

Furthermore, interpretation of music learning activities with individual approach in the cello classroom and violin B can be seen in Figure 8 and Figure 9. 


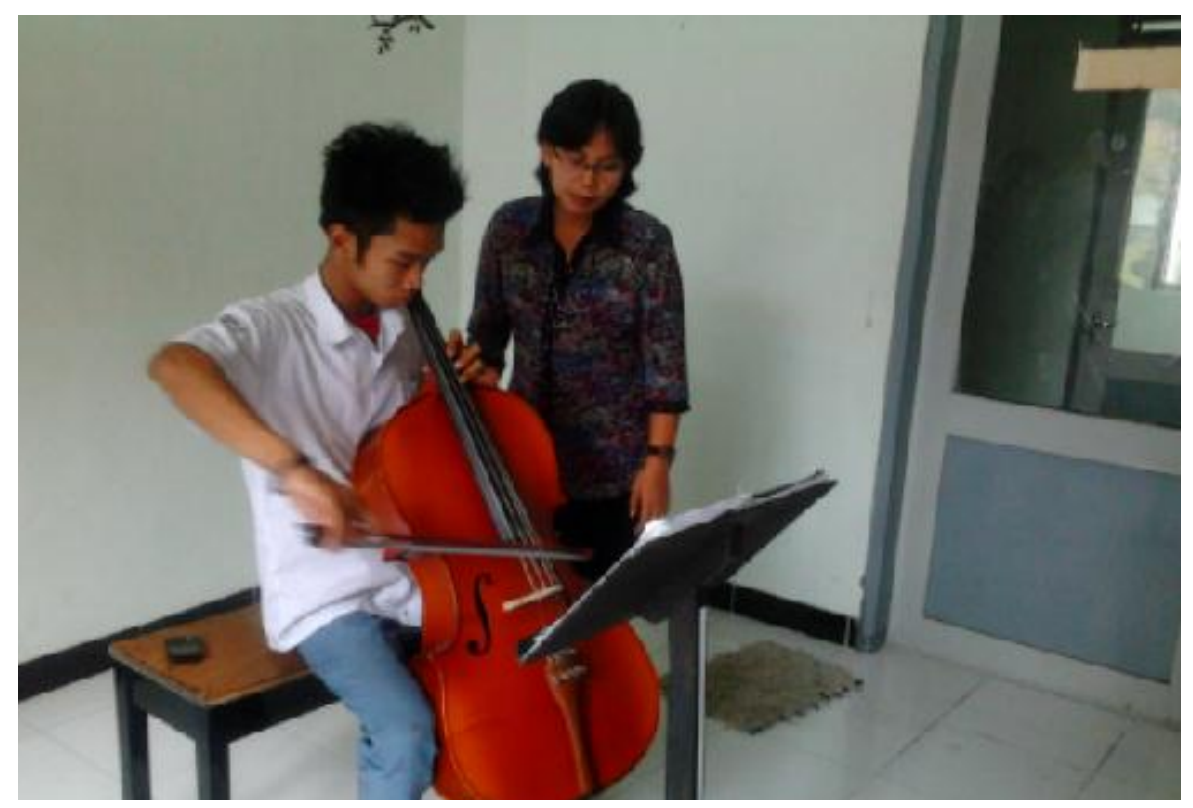

Figure 8. Cello teacher teaches student of class XI individually (Collection: Ayu, 2012).

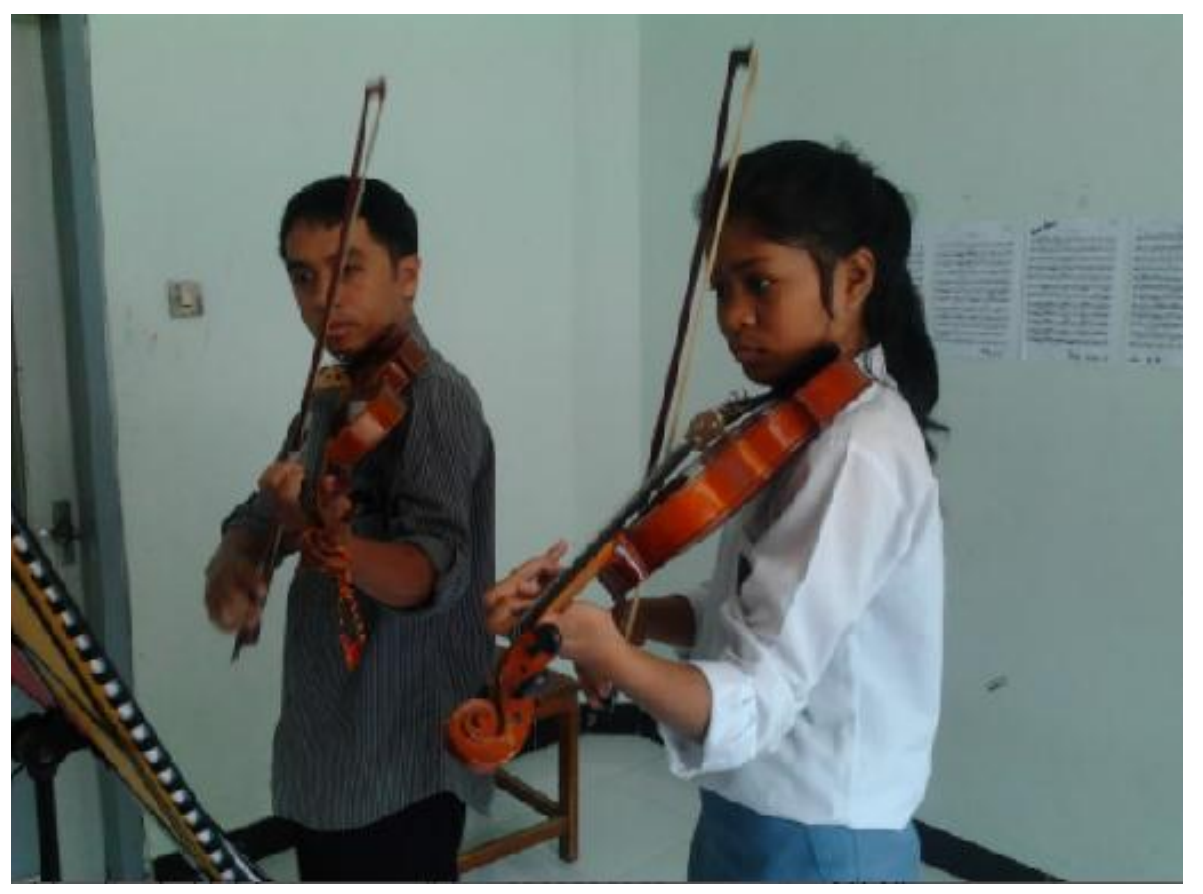

Figure 9. Violin teacher B teaches students of class XII individually (Collection: Ayu, 2012).

Based on interviews, figure 8, and figure 9 it can be said that the teacher uses an individual approach meant that the interpretation of music teaching in the instrument practice learning can be more focused and more detailed in controlling students' skills in practice. Though the number of students who take learning practices in the classroom cello instrument there are 7 people, which is divided into 3 and 4 students of class XII student of class XI). Meanwhile, in the violin class B number of students who take learning amounts to 2 students. The effect of an individualized approach to learning in both the classroom, then the teacher needs to provide its own time outside 
the scheduled time.

Based on the research results obtained, the stages through which teachers and students in the learning interpretation of the music varies in each stage of learning, both in the opening stages (apperception), implementation, and evaluation stages and cover. Opening stages, namely open learning activities is one important part in the learning process. Most of the teacher started the lesson with a relaxed atmosphere with first greeting and immediately asked the tasks that have been given in the previous week (in class guitar, cello, trumpet, vocals A, B vocals, piano, contra bass, and oboe). This is done to remind the student to his duties, and once teachers see and assess the seriousness of the students in learning. Meanwhile, in another class (saxophone, clarinet, and violin A) learning begins with prayer first, followed by tuning (in the violin class A). In class saxophone and clarinet followed by heating the play scales, which at the same time learn about the timbre (tone color). This is done also in the vocal class B. In this class, learning activities initiated by heating (vokalisi), where the previous teacher asks about the tasks given. In contrast to these classes, violin class B, learning begins with the teacher asking students to fill out the attendance list first (as shown in Figure 2).

From what has described, it can be said that most of the teachers do the same thing in starting learning the musical interpretation, namely greeting and asking the tasks given to the subjects discussed before giving the new, while some of teachers do different, such as praying, heating, and complete the administration of (fill in the attendance list). Thus, activities that have been carried out by teachers in learning begin (apperception) is said to act as a business teacher in creating an atmosphere to start the mental preparation in learning, and motivation to lead students in learning. In this case, the teacher has created an atmosphere that is fun for the students, so that, expect students' attention can focused on what will be learned. Teachers can obtain information about the readiness of students in participating in learning, and determine the level of achievement of predetermined competencies of learning material provided on the previous week. Therefore, for the learning process can be run properly and effectively, it is necessary that the teacher's role can manage the class include the ability in terms of open learning. This capability is still room for improvement in teachers who teach music interpretation.Furthermore, the core activities of the implementation of learning musical interpretation. This activity is the main activity of learning, and play an important role in achieving the learning objectives have been determined. The core activity is also an activity that can shape the ability and competence of students in learning music interpretation.

From the research that has been obtained, the activities carried out by the teacher in teaching outline music interpretation is not much different from one another. That is, all teachers practice the instrument that is the subject of research, the teaching is more focused on music interpretation of teachers themselves. This strategy is a strategy ekspositorik (Majid, 2013: 71), that is learning strategy is more teachers oriented. This strategy is also called direct learning strategies. It means, learning is much directed by the teacher (Majid, 2013: 73). In this strategy, the teacher has to process all the learning material in the form of finished goods and then delivered to the students, so 
the teacher does not involve students to play an active role in learning. More teachers to guide students in reading and playing notation correctly, explaining frasering techniques, and explain things that are technical, especially in class X. In addition, interpretation of music in the learning process, teachers do not give students the opportunity to ask. Thus, the learning process takes place in one direction. It means, the learning process is controlled by the teacher. This condition occurs in all classes of instrument practice that is the subject of research.

The use of direct strategies that teachers do in teaching the interpretation of music has its own advantages and weakness. The surplus is easy to use and implement this strategy by teacher, while weakness is less able to develop the ability of teachers and students in learning skills of music interpretation. Not only this, but also the teachers can not develop students' abilities and skills in critical thinking, problem solving, and can not develop an attitude. Therefore, a strategy that has been used by teachers in teaching music interpretation needs to be combined with other learning strategies (Majid, 2013).

Learning strategies cannot be separated from any use of methods, media, and use a variety of learning resources. This is expressed as Ihsan (2008: 8) which has been described in the previous section. The same thing also expressed by Sanjaya (2008: 3 ) who said learning strategy is a plan of action (sequence of activities), including the use of methods and utilization of various resources or strength in learning. Both strategies designed to achieve certain goals. Based on the description, and see the results of this research have been obtained, it can be explained that the interpretation of music learning, all teachers in classroom practice that is the subject of research instruments use the lecture method, imitation, practice (drill), and the method of demonstration. On implementation, the use of these methods collaborated with each other, so as to complement each other and learning objectives that have been determined to be achieved.

The use of these methods as shown in the vocal class B. In the learning process, teachers usually give first examples demonstrating the capabilities and skills in singing, while the students' attention to what is exemplified by the teacher. After that, students were asked to sing it with a technique that has been exemplified by the teacher. Of the activity in the learning process, it appears that the teacher uses two methods simultaneously, the method of demonstration and imitation method, whereas the other method is a method of exercise (drill) is used when the teacher asks the students to repeatedly practice the techniques that are considered difficult, and the lecture method used by the teacher when explaining the techniques contained in the learned song material. Similarly in saxophone class, teachers much more to use the lecture method and the method of imitation. Based on the research results obtained, this is because the skill level of the students playing instruments is still low, and student motivation in participating in learning is also low. In fact, in practice, teachers have been trying to motivate students (as seen in the results of the interview), but there is no development. 
Lecture method used by the teacher in the saxophone class, XII class is to convey information about matters related to the interpretation of the music dimension of knowledge that includes frasering, breathing techniques, and reading notation and rhythm correctly. It is not much different from what teachers do in the vocals B classroom. Furthermore, imitation method used by the teacher to give an example to students learned about playing music. In addition to the lecture method, the method of imitation, and methods of training (drill) that is used by teachers in teaching the interpretation of music, the teacher also uses an individualized approach (especially in grade cello, violin B, vocals A, and vocals B). With this approach, because the teacher wants to hold the approach and help students directly so that students can solve the problems it faces in the following study of music interpretation. This is seen in the violin class $B$, where teachers want to teach more detail in a music interpretation to the students, so in the learning process, the teacher in turn teaches students (individuals). Similarly, in grade cello, and vocals B.

In the interpretation of music teaching, some teachers (in the vocal class A, class saxophone, and cello classes) using instructional media such as a CD player, 14-inch TVs, and laptops. However, this medium is used only to accompany the student at the time played a piece of music is learned. The reason for using the media (especially in the vocal class A), due to the difficulty of finding students who took the piano to accompany, so that teachers using media such as a CD player and a 14 inch TV. In this case, Yhn L. S (vocal teacher in class A) has a high motivation to advance their students to be able to practice to the fullest. It was said, because in the procurement of the media, teachers conduct self-financing basis. Actually, this can be a concern the school to provide a better means of learning media such as audio or audio-visual form as a supporting practice learning a musical instrument especially interpretation learning. although the school has to provide a means of CD player.

Meanwhile, the use of media with the same purpose (just to accompany the students to play music), also conducted in-class saxophone and cello. If on the saxophone class using a player $\mathrm{CD}$ to accompany the students to play music, cello teacher in the classroom using a laptop for the same activity. This is unfortunate, because it is basically the use of these media can be utilized more maximal, especially in music interpretation learning.

In this lesson, the teacher can listen to the music playing from professional musicians to students. By listen the music playing, teachers can develop students' skills of music interpretation. It is as said by Reid (2002: 107) "listening to good performance of others is the most effective means of developing interpretative skills". Reid expression reinforced by Colwell (2010: 100) which states "Most music teachers get a smattering of knowledge about style from their college courses, but this usually should be augmented by listening to authoritative performances for enhancing interpretation ability". From these two expressions, it can be said that teaches students to listen to the music from professional musicians is important. Said to be important because in presenting a piece of music (Sloboda in Reid, 2002: 107) first was needed the expertise analyzes of the power of listening developed from the type of piece of music being played, so it 
can be attached multiple times and different intensities (ie dynamic) which makes a presentation of the music for the better, and then mimicking the musician playing.

Further Sloboda (in Reid, 2002) describes the expressive techniques passed from one musician to another musician with a demonstration. That is why great musicians (master) is almost always interested in and passionate musicians heard the music of other masters. Thus, the importance of listening play of professional musicians (master). These activities can also foster the musical experience for students. Therefore, the teacher can actually teach the interpretation of music, one of them by listening to playing of music of professional musicians (master). However, based on research results obtained, it is not done during teaching the interpretation of music in instruments practice learning.

\section{CONCLUSION}

In teaching music interpretation, self-management strategies used by teachers including motivation, teaching methods, and monitoring performance. Some teachers are motivated to use audio media only to accompany the students while singing or playing an instrument (in a vocal class, saxophone, and cello). The media is not being used to teach students to listen to music from professional musicians. In vocals class B , teachers of motivate themselves to accompany students to sing by playing the piano. Meanwhile, in violin class A and viola class B, do not use the music for her students who play violin.

In addition to motivation, the teacher uses multiple teaching methods combined with each other. The teaching methods used in the interpretation of music learning are the lecture method, the method of imitation, demonstration method, and drill method. Some teachers also use an individual approach to teaching musical interpretation (cello class, and violin class B). Related to monitoring performance, all teachers practice the instrument, constantly monitor the performance of the students in the form of instrument practice and practice singing (vocal class).

From what has been described, it can be conclude that teachers use self-management strategies in teaching the interpretation of the music. The components of selfmanagement used by teachers are the motivation, methods of learning, and performance monitoring.

Based on this, the teacher needs to improve self-management skills (Dembo, 2004) as the process self-manage of increasing academic behavior. It is hoped that teachers can control the factors that affect its learning.

\section{REFERENCES}

Colwell, R. J. (1970). The Teaching of Instrumental Music. New Jersey: Prentice Hall, Inc.: 99.

Davie, C.T. (1996). Musical Structure and Design. New York: Pan American and International.

Dembo, H. M. (2004). Motivation and Learning Strategies for College Success: A SelfManagement Approach. London: Nw Jersey. 
Gerring, J. (2007). Case study research: principles and practices. Cambridge: Cambridge University Press.

Gillham, B. ( 2000). Case study research method. London: TJ. International, Ltd.

Ihsan. (2008). Pengembangan dan penerapan model pembelajaran berbasis kompetensi. Jakarta: Dikdasmen.

Kitelinger, S. ( 2010). Musical performance for the instrumental conductor. Makalah disajikan pada Clinic from CMEA. SBS Conference 2010.

Majid, A. (2013). Strategi pembelajaran. Bandung: PT. Remaja Rosdakarya.

Matthay, T. (1913). Musical interpretation. Boston: Stanbope Press.

Reid, S. (2002). Preparing for Performance. In Rink, J. (eds). Musical Performance A Guide to Understanding. New York: Cambridge University Press:103-110.

Sanjaya, W. (2008). Strategi pembelajaran berorientasi standar proses pendidikan, Jakarta, Kencana. Jakarta: Media Prenada.

Satori, Dj. \& Komariah, A. (2011). Metodologi penelitian kualitatif. Bandung: Alfabeta.

Surya, M. (2004). Psikologi pembelajaran dan pengajaran. Bandung: Pustaka Bani Quraisy.

White, J. C. (2009). Teaching musical interpretation. NACWPI Journal, Summer 2009.

Wong, L. (2012). Essential study skills, $6^{\text {th }}$ edition Boston: Cengage Learning Publisher.

\section{ONLINE RESOURCE}

Ford, M. (2011). Marimba: an interpretation. Access on January $20^{\text {th }} 2012$ from http:// www.innovativepercussion.com/docs/documents/405/MarimbaAnInterpretation. pdf. 